Article

\title{
Reverse Causality between Oil Policy and Fiscal Policy? The Venezuelan Experience
}

\author{
Osmel Manzano ${ }^{1, *}$ and Jose Luis Saboin ${ }^{1,2, *}$ \\ 1 Inter-American Development Bank, Washington, DC 20577, USA \\ 2 Department of Economics, George Mason University, Fairfax, VA 22030, USA \\ * Correspondence: osmelm@iadb.org (O.M.); jluissa@iadb.org (J.L.S.)
}

check for

updates

Citation: Manzano, O.; Saboin, J.L. Reverse Causality between Oil Policy and Fiscal Policy? The Venezuelan Experience. Energies 2021, 14, 2574. https://doi.org/10.3390/en14092574

Academic Editor: David Mares

Received: 30 March 2021

Accepted: 26 April 2021

Published: 30 April 2021

Publisher's Note: MDPI stays neutral with regard to jurisdictional claims in published maps and institutional affiliations.

Copyright: (c) 2021 by the authors. Licensee MDPI, Basel, Switzerland. This article is an open access article distributed under the terms and conditions of the Creative Commons Attribution (CC BY) license (https:// creativecommons.org/licenses/by/ $4.0 /)$.

\begin{abstract}
This paper uses a model of intergenerational accounting to simulate the intergenerational distribution of oil wealth in Venezuela. Venezuelan oil production does not seem to follow an optimal extraction path. Nevertheless, this is true if we do not consider what the government does with the resources received from the oil sector. We explored the interaction of oil policy and fiscal policy using such intergenerational accounting model. We argue that the way in which tax revenues (both, those coming from oil and those who do not) are used today can affect voters preferences on how they will be used tomorrow. These interactions could explain certain outcomes. In particular, the model could explain why the sector was open for investment in 1991 and then "re-nationalized" in 2001. Results suggest that when fiscal policy could leave an important burden to future generations, voters seem to favor a more tax-oriented oil policy, leaving the oil in the subsoil.
\end{abstract}

Keywords: oil policy; fiscal policy; intergenerational accounting; fiscal voracity; oil expropriation cycles; Venezuela

\section{Introduction}

The role played by natural resources in development has been part of the economic policy debate for some time. From the works of Prebisch (1950) [1] and Salter (1959) [2] to the works of Sachs and Warner (1995 [3] and 1997 [4]), there has been a perception that resource abundance is bad for development. Though the work of Salter (1959) per se does not attribute any negative effects to natural resource abundance, it is the reference used to characterize the "Dutch Disease". This term is used to describe the "de-industrialization" of a country after a resource boom. The term was coined by the magazine The Economist in an article about the Netherlands [5].

Nevertheless, a problem with this literature is the lack of evidence on the precise channels that produce this negative effect. For instance, Georgescu-Roegen (1976) [6] argues that the viable and available resources depend on the existing technologies at the current time horizon and society's consumption patterns, therefore the negative effects could be the result of rational anthropomorphic activities. In other words, there is a stylized fact. However, some recent works have cast some doubts even about these stylized claims [7].

There are some potential hypotheses to explain why this phenomenon occurs. Nevertheless, the evidence about bad outcomes from these explanations is weaker. Probably the best proven fact is that there is "Dutch Disease". Stijns (2003) [8] uses a gravity model of trade and finds evidence on Dutch Disease. However, there is no evidence that this has a negative impact on growth or welfare. One of the main channels that the literature has proposed for the transmission of this "resource curse" is macroeconomic volatility. Traditionally, macroeconomic volatility (i.e., high degrees of variation in one or several macroeconomic variables) has been associated with negative effects on economic performance [9]. For the case of resource-abundant countries, Hausmann and Rigobon (2003) [10] present a model that links volatility to poor economic performance. 
In their model, Hausmann and Rigobon (2003) argue that in an economy with adjustment costs, real exchange rate volatility could induce lower investment in the tradeable (i.e., exportable) sector. Basically, this volatility does not allow economic agents to predict the future real exchange rate, and therefore they do not know which tradeable projects are profitable or not. Since this uncertainty does not affect investment in non-tradeable (i.e., non-exportable) sectors-because profits and costs are set in the same currency-the economy ends up inefficiently specialized in non-tradeable goods. Consequently, this volatility generates welfare losses.

How does the natural resource sector generate such volatility? As argued in Manzano (2002) [11], commodity prices are highly volatile. However, the fact that these exports have volatile prices does not necessarily imply that producers will have unstable economies. As described in Manzano (2002), there are different channels (i.e., vehicles) that can "transmit" this external volatility into the country's gross domestic product. Firstly, additional external factors can compound this external volatility. Manzano and Rigobon (2007) [12] found that the traditional estimations of the "resource curse" are not robust to the introduction of a "debt overhang" (i.e., a debt level so high that a country is impeded to grow) variable that basically implies that resource abundant countries received important capital flows in the seventies when prices were high but were faced with no access to external markets when prices fell in the eighties.

Besides the external factors, there are three important domestic factors. One is the government through its fiscal policy. Engel and Valdez (2000) [13] and Sachs (2006) [14] provide a review of the interactions between fiscal policy and resource booms. More recently, van der Ploeg and Venables (2008) [15] present a complete menu of options of fiscal policy for countries with abundant resources, depending on the initial conditions of the countries and the nature of the resource endowment. The second channel is the financial sector [16]. Finally, the third channel-that is completely related to the previous two-is monetary policy. In most cases, monetary policy has to adjust to the decisions of the fiscal authorities and to the financial sector.

As argued by Raddatz (2005) [17], domestic factors explain more of the output volatility of developing countries than external factors. Consequently, the general argument has been that resource shocks generate certain responses by policy makers and, depending on the nature of those responses, there could be good or bad outcomes. Less discussed and evident is the fact that those policy responses could affect the way the resource sector behaves and, consequently, they could condition future shocks.

There is an important literature on the so-called "expropriation cycles" [18]. This literature highlights the fact that "implicit" tax rates are not immune to price cycles. When prices are high, governments in resource-rich countries have incentives to expropriate the rents derived from them. On the other hand, when prices are low, governments have incentives to attract investors and offer better fiscal conditions. Consequently, there could be an "amplification" of the cycle due to tax changes.

Nevertheless, the most important effect is in the long run. As argued in Manzano and Monaldi (2008) [19], oil production has a long cycle from the moment a decision of investment is made to the moment that oil is produced, even more so if the cycle also includes exploration. Therefore, expropriation cycles affect the long-run level of resource production. As a result, as price volatility has effects on fiscal performance today, fiscal decisions today could affect the nature of oil shocks in the future. In Venezuela, the earliest example was the price cycle of the early eighties when production was low-in spite of higher prices-due to an earlier expropriation cycle that led to nationalization [20].

In this paper, we move a further step back. In particular, a good question is why these expropriation cycles continue to occur. Manzano and Monaldi (2008) present some ideas about the possible explanation of these cycles, basically, there are two important drivers: (1) lack of "progressivity" on oil taxation and (2) the particular characteristics of the oil sector that makes it prone to these cycles. However, even considering these arguments, it could be argued that there are instruments that could help avoiding these cycles. In 
this regard, we try to explain the Venezuelan cycles using the models of intergenerational accounting of Auerbach, Gokhale, and Kotlikoff (1991) [21]. We will argue that the fiscal performance of different Venezuelan administrations could give incentives to voters to change their stance on oil policy.

Traditionally, the literature has studied how the income from natural resources affects their fiscal use. Videgaray (1998) [22] and Bozzari and Rincon (2002) [23] provide two important studies on this matter. What we propose in this paper is that the way in which tax revenues (both, those derived from natural resources and those that are not) are used today can affect voters preferences on how they will be used tomorrow. For this reason, in this paper we argue "reverse causality". To the best of our knowledge, only one paper by van der Bremer et al. (2016) [24] explores the relationship between leaving oil in the subsoil and fiscal policy.

The paper is organized as follows: Section 2 presents a review of Venezuelan oil policy. Then, in Section 3 the framework of intergenerational accounting is presented and adapted to a natural resource abundant country such as Venezuela. In Section 4, the generational accounts of 2001 are presented. Section 5 presents the generational accounts of 1975 and 1991. Finally, Section 6 concludes.

\section{A Review of Venezuela's Oil Policy}

A previous study by Fernández and Gómez (2001) [25] determined that in 2000, newborn Venezuelans and the future generations in this country will enjoy fiscal benefits for the rest of their lives, which suggests that the Government's fiscal policy is sustainable if the oil exploitation path is optimal. This result is different from most findings about intergenerational policies applied in other countries, since there exists a growing concern regarding the generational burden of future generations resulting from the social welfare programs that try to benefit living generations [26]. A particular concern is the demographic transition-when fertility rates begin to fall-and its impact on social security systems, especially on pay as you go systems. See, for example, the works of Laub and Hagist (2017) [27] and Arévalo et al. (2019) [28].

The aforementioned study assumes the Venezuelan Government finances its expenditures by exploiting oil-derived resources; thus, it does not need to impose taxes that increase the generational burden of living and future generations. Therefore, the definition for the generational accounts was modified for the Venezuelan case, since the intertemporal budgetary restriction must include the benefits derived from the oil exploitation.

Generational imbalances vary depending on the premises used for calculations, specifically the rate of growth of the oil sector and the non-oil sector of the economy, as well as their degree of interdependence. The resulting fiscal revenue series derived from such premises stress the need of modifying fiscal benefits to achieve intergenerational balance.

In an implicit manner, the study concludes that oil exploitation is indirectly financing taxes that generations would have to pay to support Government expenditures. The study also concludes that a raise in the level of expenditures, a different path for oil exploitation, or a different price for the oil barrel affects fiscal revenues with intergenerational consequences.

It is important to mention once again that the conclusion is based on the premise of an optimal exploitation of the oil resources. The model, detailed in Appendix A, is based on a previous work done by Medina (1997) [29], which is an adaptation of a paper by Deacon (1993) [30] for the United States. Nevertheless, it is not obvious that oil exploitation follows this path in Venezuela.

Without entering into the specific details, one of the key principles that has driven oil policy in Venezuela, since the inception of Democracy, is "preservation". The preservation principle was based on the notion that oil is a scarce resource of great value, and therefore Venezuela has to minimize its extraction in order to save it for the future.

This principle is mostly associated with democratic governments, and Juan Pablo Perez Alfonzo [31] is recognized as the main ideologist behind it. Urbaneja (1992) [32] 
and Baptista and Mommer (1987) [33] wrote comprehensive accounts on the topic. Prodemocratic forces accused authoritarian governments, from the first half of the twentieth century, of "giving away" Venezuelan oil, and it became a relatively successful political platform. Once democracy was instituted, it became a main guideline for the different administrations, and gave way to the "no-more-concessions" policies as well as the eventual nationalization in 1975.

This principle of preservation resulted in policies that increased the government's claim on profits from the sector. The government's claim on oil profits increased and almost reached $100 \%$ in the years prior to the nationalization. The argument was that since oil is such a valuable commodity of limited availability, the government, as the owner of the resource, should maximize its share of the rents generated by the sector.

The instrument used to achieve this goal was the tax system through two different options: the income tax and the royalties. But also, to generate more income tax, there was the rule of "the fiscal value of exports" which was the price of oil that had to be used to calculate the income tax, fixed by the government at levels usually higher than the market price. Later, well after the nationalization, the rule was eliminated but the "dividends" from PDVSA were used as another way to collect taxes from the sector.

As a result, as seen in Figure 1 below, the extraction rate of oil in Venezuela has been declining and has stayed relatively low. As the reader will notice, the line is presented broken, because important revisions were made to the reserve total in 1975, 1987 and 2009. However, it is clear from the graph that the described trend is present in all sub-periods.

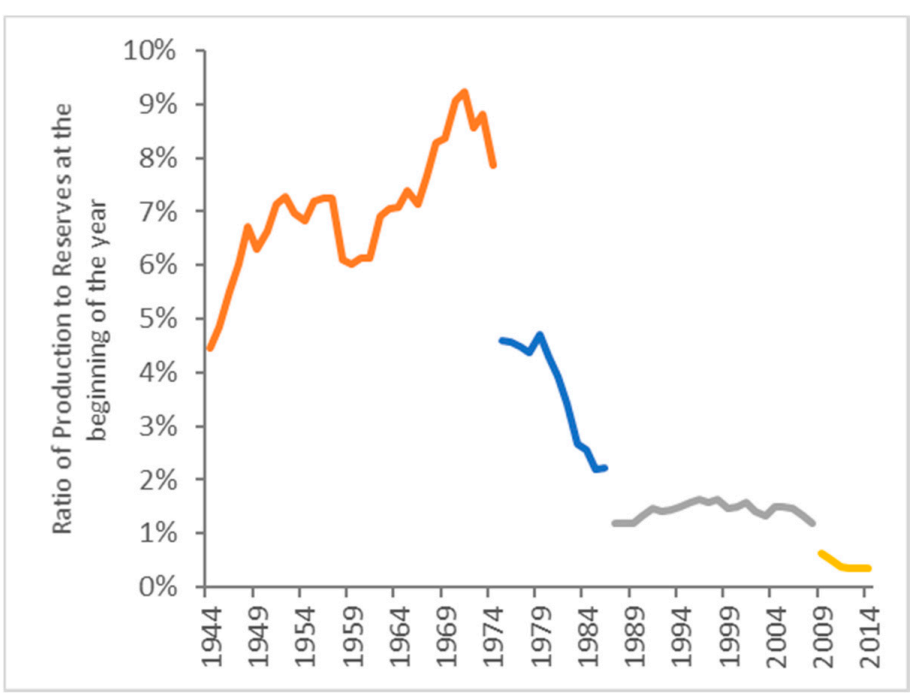

Figure 1. Extraction rate. Source: Ministerio de Energía y Minas (various years).

Nevertheless, even in spite of this low rate, there have been policy shifts. Manzano and Monaldi (2010) identify different cycles of openness and expropriation in the Venezuelan oil sector. In particular, there was a renegotiation in 1943 that at the same time allowed the development of the sector. Later, the sector was nationalized in 1975. Then, the oil sector was opened up to private investors in the 1990s. Finally, the government expropriated private investors again at the beginning of the 2000s.

The authors conclude that, even though ideology might have been important in framing the policy options, the distributive conflict and the lack of an effective tax system, which would allow the government to effectively collect rents, should not be overlooked. In addition, incentives intrinsic in the oil sector make the industry a tempting target for expropriation. In particular, since the oil cycle-between investment and production-is long and the fact that most of the investment is sunk and cannot be moved out of the project once it is done, oil is vulnerable to be expropriated once investment is done and production is flowing. This could be aggravated in weak institutional settings, where the 
administration benefiting from the revenues is different to the one that allowed investment in the first place.

Given this pattern, is the preservation principle rational? As shown in Figure 2, we compare the extraction rate with its "opportunity cost". In particular, the orange line represents production in $t$ compared to the production in $t+10$ [34]. The blue line represents the ratio between the "return" of an oil barrel (the ratio of the price in $t+10$ and the price in $t$ ) and the return of a 10-year government bond [35]. In other words, it presents the difference between the realized oil price growth in the next 10 years minus the implicit interest rate of the Venezuelan debt.

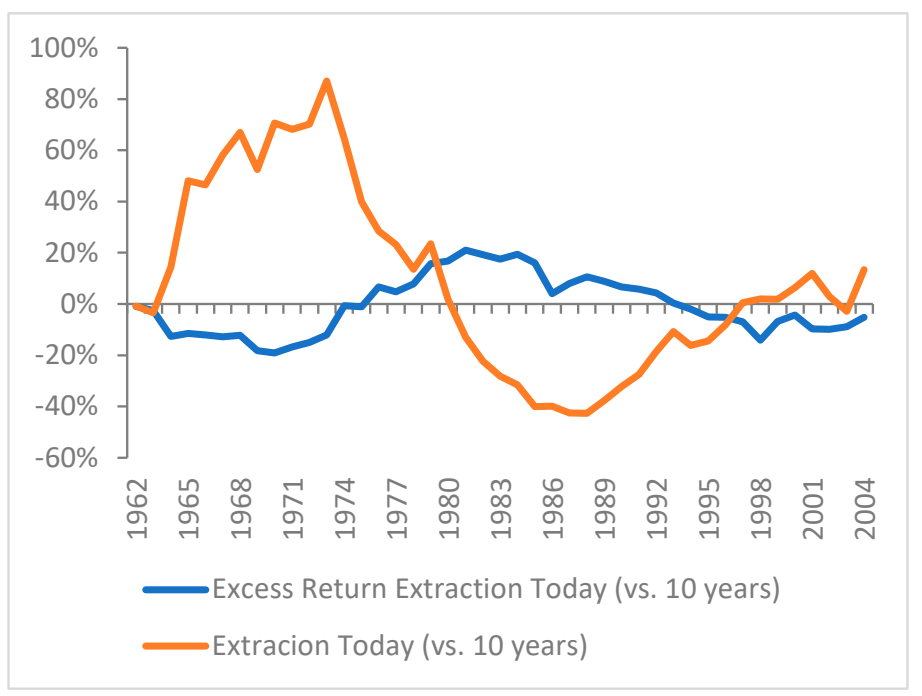

Figure 2. Returns of extraction vs. extraction. Source: Authors' calculations.

We estimated the net rent (i.e. price net of costs) consistent with the model used in this paper. However, a more specific estimation could be done using the "Hoteling rent" model: the difference between the price and the total cost, including extraction costs (there are other approaches to estimating this rent, see for instance: Georgescu-Roegen (1979) [36]). Unfortunately, not all the information is available for the complete period. Nevertheless, the figure offers a good approximation. It does not seem that the low extraction rate is the optimal strategy. The lines move in opposite directions: when the return to extract today - the blue line in the chart-increases (decreases), extraction today-the orange line-decreases (increases).

Therefore, it seems that there is a prevalence of the preservation principle. Consequently, this evidence suggests the relevance of studying the use given to oil fiscal revenues in order to understand why this lack of production optimization has been so prevalent.

These results are consistent with Manzano (2015) [37], which evaluates oil policy from the point of view of oil being managed as an asset by the State in different developing countries. The pattern detected in Latin American countries is similar to these patterns. In the paper, the author finds that countries with better investor perceptions of the tax system, regulation compliance, and regulatory certainty tend to have long-term reactions to oil extraction consistent with its return. Therefore, it appears from these results that better institutions allow for long term planning and management of the resource.

\section{The Intergenerational Accounting Framework}

In the present analysis, we make use of the Generational Accounting methodology developed by Auerbach, Gokhale, and Kotlikoff (1991) for analyzing the effects on the generational balance between living and future individuals.

Generational accounting is based on an intertemporal budgetary restriction: government expenses minus financial assets must be paid by present or future generations. 
This is clearly expressed in the following equality:

$$
\sum_{k=t-D}^{t} N_{t, k}+(1+r)^{-(k-t)} \sum_{k=t+1}^{\infty} N_{t, k}=\sum_{s=t}^{\infty} G_{s}(1+r)^{-(s-t)}-W_{t}^{g}
$$

The first sum on the left side of (1) represents generational accounts of living individuals, that is, the present values of the net payments that must be rendered to the government. Such generational accounts are taxes paid minus transfers received. The second sum in the left side of (1) represents the present value of future generations' accounts. Both generational accounts are expressed in monetary terms and must be discounted to $t$.

The first term on the right side of (1) is the present value of government consumption in time. The second term is net wealth (assets minus debt) in year $t$. All variables are measured in year 2000 USD.

where:

$N_{t, k}=$ generational account at year $t$, of a cohort born in year $k$

$k=$ year of birth of each generation, from $t-D$ to $t$

$D=$ years lived of a generation born in $k$

$t=$ base year

$G s=$ government consumption at any year

$S=$ any year between $t$ and $\infty$

$W_{t}^{g}=$ government's net wealth (assets minus debt) at $t$

Equation (1) shows that generational fiscal policies are a zero-sum game. Given the present value of government consumption, a decrease in generational accounts of living individuals must be accompanied by a raise in future generations' accounts.

Generational accounts $N_{t, k}$ are defined by taxes paid minus transfers received in time, in present value, for each generation. Being:

where:

$$
N_{t, k}=\sum_{s=K}^{k+D} T_{s, k} P_{s, k}(1+r)^{-(s-K)}
$$

$K=\max (t, k)$

$T_{s, k}=$ net tax payment (taxes paid minus transfers received)

to government in year $s$, by a member of generation born in year $k$

$P_{s, k}=$ number of living individuals in year $s$, of generation born in year $k$

For generations born before $t$, the sum begins in $t$ and is discounted to $t$

For generations born in year $k>t$, sum begins in $k$ and is discounted to $t$

Generational accounts are a group of $N_{t, k}$ values where there is a $N_{t, k}$ value for each generation, present or future.

If generational accounts for future individuals are greater than for present individuals, fiscal policies are not sustainable and Equation (1) is unbalanced. The same happens if the case is contrary for living individuals.

The main source of income in Venezuela is oil exploitation (in 2000, oil revenues accounted for $51.81 \%$ of the total national budgeted income). Therefore, an analysis of the problems related to the generational imbalance must consider that the Venezuelan State owns the resource, as well as the fact that the high proportion of oil-derived revenues may be indirectly financing the taxes that living or future Venezuelans would have to pay. In this regard, the generational burden or benefit of living generations in Venezuela would be more associated to the income the State is able to gain from the exploitation of oil than from taxes levied on generations.

The government fiscal revenues from the oil sector comprise royalties, oil income tax, other oil taxes, and the dividends paid by the company that exploits oil. Therefore, we assume that the State is financing part of its revenues with oil and not relying only on non-oil taxes, and non-tax non-oil income (i.e., revenue that does not come from neither oil nor taxes). 
As a result, the intertemporal budget restriction is modified in the following manner:

$$
\begin{gathered}
\sum_{s=2001}^{\infty} \operatorname{Pet}_{s}(1+r)^{-(s-2001)}+\sum_{k=1902}^{2001} N_{2001, k}+(1+r)^{-(k-2001)} \sum_{k=2001}^{\infty} N_{2001, k} \\
=\sum_{s=2001}^{\infty} G_{s}(1+r)^{-(s-2001)}-W_{2001}^{g}
\end{gathered}
$$

where Pet is the present value oil income (not including dividends). The time projections of the data series last 100 years. Since our first period of interest is 2001, the base year is 2001 (when the last cohort of individuals from the present is born). From 2002 on, new generations (future generations) are born.

\section{Intergenerational Distribution of Oil Wealth in Venezuela in 2001}

Given the framework discussed in the previous section, the next step is to calibrate the model. The discount rate used is $11.35 \%$, corresponding to the distribution of oil and non-oil income and a weighted average (50-50\%) of the long-term public debt yield issued by the Government and the bond yield of PDVSA (the Spanish acronym for Petróleos de Venezuela, the national oil company) in the international stock market. This rate reflects, besides the cost of debt, the perspective on the efficiency of the government to collect taxes, as well as the probability of obtaining oil income. In Appendix B, we present the results with an alternative rate of $5 \%$ (the historical rate for a sovereign emerging market issuer). For these calculations we used historical series from Venezuela's Ministry of Finance and Ministry of Energy and Mining.

Generational accounts (taxes minus transfers) are thus comprised by the following burdens and benefits that present and future individuals will enjoy in their lifetime:

(1) Income tax (non-oil)

(2) Other taxes (non-oil)

(3) Non-oil revenues nontaxes revenues

(4) Government transfers, including health, education, and social security.

It is important to mention that taxes are calculated as a proportion of non-oil GDP. Such proportions are constant in time. Additionally, we assume that the Government is always able to collect taxes from individuals. With respect to generational accounts, transfers and administrative expenses are determined to the total level of expenses. We assume that transfers are deducted from paid taxes. For these variables we used historical series from the Ministry of Finance.

Additionally, we assume that net wealth (W2001) is formed by international reserves, including the Macroeconomic Venezuelan Stabilization Fund (FIEM) minus the external debt in year 2001. We do not consider domestic debt, due to the particular characteristics of Venezuela. In the past, the government has printed money or applied exchange rate policies that have "liquidated" the domestic debt value every time it became burdensome. These data was obtained from the Ministry of Finance and the Central Bank.

Finally, the real GDP growth rate assumed is the average historical rate for the 1958-2000 period: $3.56 \%$. In Appendix B, we present the results with an alternative rate: that of the non-oil GDP "that does not depend on oil", which is assumed to grow at $0 \%$. This is based on the historical performance of that variable in Venezuela. Actually, in the last 25 years, this variable has been negative; therefore, this assumption is on the "optimistic" side.

We construct two alternative oil production scenarios. One scenario assumes that oil production follows the optimal extraction path—as in Fernandez and Gomez (2001) — that we call "optimal oi policy" and a second, historical one, is called "business as usual". In both cases, prices are assumed to be constant. Given the evidence presented in recent literature, like Cuddington et al. (2007) [38] and Rigobon (1998) [39], this assumption seems reasonable. Moreover, for the general qualitative results of this model to be true, oil prices could increase in real terms as long as they do so at a pace slower than the interest rate. 
The "optimal oil policy" scenario assumes that there are no taxes and that the government gets a share of the profit. The share of the profits is the same as the effective tax rate. Because the distortionary effects of taxes are removed when the government shares profits, the production path is optimal. We take that optimal scenario. In "business as usual", we leave the taxes as the mechanism for the government to collect revenues from the sector. As shown in Smith (2020) [40] and Davis and Smith (2020) [41], these assumptions are not far from reality. Taxes such as those referred as "factor- $X$ " taxes, are similar to pure profit taxes in Latin America, and for Venezuela, the extraction path would be close to the optimal path without taxes.

In Figure 3, we present the fiscal accounts for each generation, following the standard methodology from Auerbach, Gokhale, and Kotlikoff (1991). For each of the scenarios we calculate the level of generational imbalance, using the programming model developed by Phillip Oreopoulos, "Generational Accounting". The software used was MATLAB version 21.0. In the horizontal axis are the cohorts (i.e., individuals in a corresponding age group), beginning with those that have not been born yet in 2001, then those born in 2001 (0), and ending with those that are 100 years old or older today (each horizontal tick in the chart represents age cohorts, 0-4 years old, 5-9 years old, . . , 95-100 years old.). Historical data and projections for Venezuela's population age and sex distribution was obtained from the United Nation's Population Division. In the vertical axis is the net fiscal payment of the cohort (i.e., the result of Equation (3)). In order to understand the generational imbalance results, we must consider that positive numbers indicate a generational burden and negative numbers indicate a generational benefit.

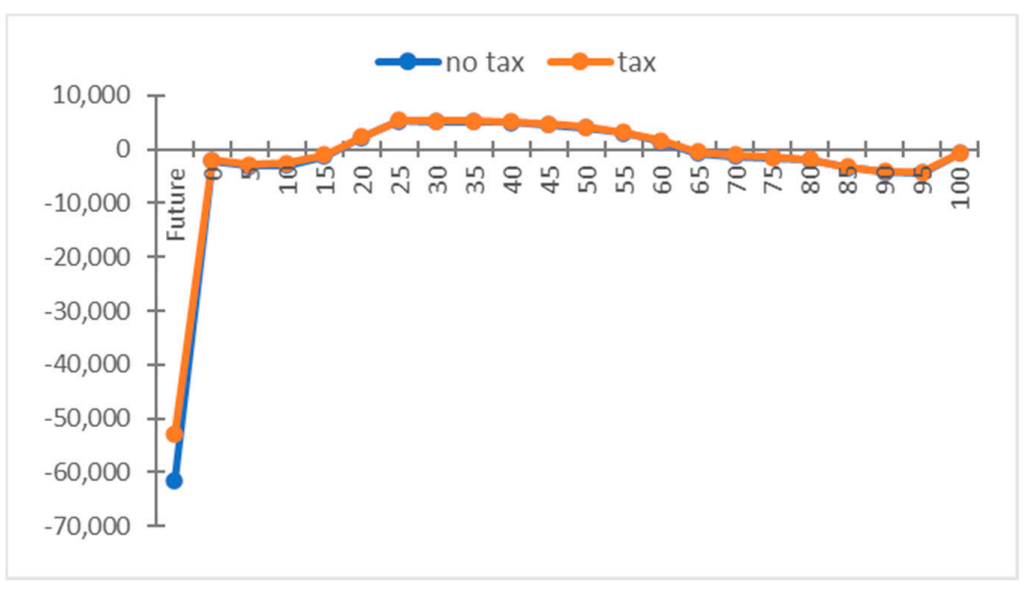

Figure 3. Generational accounts in 2001. Interest rate: 11.35\%. Constant expenditure per capita. (In year 2000 U.S. dollars). Source: Authors' calculations.

We must compare the generational accounts of newborn individuals and future individuals, since comparing different-age individuals living at the same time is not correct, as they have different years left to live. Therefore, we do not compare the generational accounts of a 15-year-old individual with that of an 80-year-old, since the young person has many years left to pay taxes and receive fiscal benefits, while the old person has less years to live (assuming they will die at the same age).

In order to compare present generational accounts with future generational accounts, we read the point in the horizontal axis marked as " 0 ", representing the generational account of an individual born in year 2001. We compare this to the point marked as "future", which represents the generational account of an average individual born after 2001.

As can be seen in Figure 3, under the assumption of keeping per capita government expenditure constant, future generations will receive a benefit, independently of the tax regime on oil activities. Moreover, an "optimal oil policy" (labeled in the chart as "no tax") will yield greater benefits for future generations when compared with the "business as usual oil policy" (labeled in the chart as "tax"). However, these results do not suggest that 
the preservation principle is based on wrong assumptions. Remember that such principle was first introduced in the sixties, and it might have been that, by the time, it was optimal. Nevertheless, what these results do imply is that in the early 2000s, it was not optimal to keep the oil underground. Moreover, it could be argued that these results seem to imply that there are no "dynasties" in Venezuela, and that the current generation only cares about itself.

These results, however, were based on the particular premise of a principle of intergenerational justice, in which the level of expenses per capita remains constant over time, so that no generation is better off than another. This, since the government will try to maintain a permanent level of consumption of the oil wealth over time, adjusting it to the growth rate of the population and also to the level of expenses per capita. As a result, in the optimal oil policy scenario (labeled as "no taxes" in the chart), fiscal balances are better than in the business as usual oil policy scenario (labeled as "taxes" in the chart).

Nevertheless, substantial empirical evidence shows that in several countries, the variations in macroeconomic variables affect fiscal outcomes in a negative manner, particularly when temporary shocks affect their terms of trade (i.e., the ratio of an index of a country's export prices to an index of its import prices). This is the case even when a temporary shock is a positive windfall over the fiscal accounts, a case perfectly portrayed in the Venezuelan economy, which is subject to shocks derived from fluctuations in oil revenues. See Radatz (2005) for an estimation of these effects.

Fiscal policy is often the mechanism for transmitting shocks in the terms of trade to deteriorate the current account. In this regard, positive shocks are often followed by a raise in fiscal expenditures in a proportion higher than the positive windfall. However, evidence shows the failure of such countries to benefit from such shocks. See Manzano and Rigobon (2007) for a possible effect of these policies.

Lane and Tornell (1998) [42], present a model where fiscal policy is determined by the interaction of several groups with power to appropriate the resources from the national budget. Such groups could be state-owned enterprises, ministries, provincial governments, strong private corporations, etc. They define the term "voracity" for describing the proportion in which these groups appropriate the tax base and public assets. The voracity effect is "a more than proportional change in expenditures in response to a shock".

Following such argument, a variation in oil prices or production levels that leads to a temporary increase in fiscal income will be depleted to a more proportional extent than the original variation. Any gain derived from a windfall will be dissipated by the appropriation derived from the powerful groups, potentially reducing the growth rate of the economy. Powerful groups try to appropriate public assets by even arguing that they are avoiding resources from being depleted by other groups, no matter if the manner in which they use the resources yields a low return.

The Venezuelan case is an excellent element of study, regarding shocks over the terms of trade, exchange rates, fiscal expenditures, country-risk, failure to manage savings funds, etc. In this regard, fiscal expenses in Venezuela have evidenced abrupt differences over time, caused by the volatility transmitted by variations on oil income.

In this regard, there are two works that have estimated the precise effects of oil shocks to fiscal accounts in Venezuela, Videgaray (1998) and Bozzari and Rincon (2002). Videgaray found that, for Venezuela as well as other OPEC countries, oil revenues impact the fiscal accounts. More specifically, he found little evidence that wealth changes-based on stock measures or predicted future value of oil revenues-impact fiscal expenditures. Nevertheless, cash flow measures do affect fiscal expenditures, without affecting non-oil tax rates. Moreover, he found that the elasticity of government expenditure to oil revenues is not symmetric. It is higher when prices move upward. This implies that a potential for fiscal imbalance exists, as actual government expenditures will not be fully reduced when oil prices move down.

Considering both approaches, for the period 1958-2000, we estimated Venezuela's fiscal expenditures elasticities to oil income variations and then changed the assumptions of 
our model. We will assume government expenditure, as a share of GDP, will change asymmetrically using such elasticities, see Appendix $C$ for results. Additionally, we will assume that the composition of expenditure-in terms of its distribution across generations-does not change, based on Bozzari and Rincon (2002). A plausible argument against this assumption is that Bozzari and Rincon (2002) did find an important difference in the elasticity for public investment and it might have an intergenerational impact. Nevertheless, we are not aware of any estimation on the returns to infrastructure investment in Venezuela, which could be used to improve the model.

Once the assumption of voracity is introduced, the fiscal behavior of the "optimal oil policy" scenario is different. In this case, fiscal expenditure will increase over time, due to the higher oil revenues. Consequently, the fiscal balance will reach a smaller surplus in the years of higher production. However, the fiscal result will become a deficit sooner, and the size of such deficit on the final year will be higher.

Figure 4 shows the results of the generational accounts when the assumption of voracity is introduced. As in Figure 3, we read the point in the horizontal axis marked as " 0 " as the generational account of an individual born in year 2001 and compare it to the point marked as "future", which is the generational account of an average individual born after 2001. From the figure, it is clear that, in the optimal oil policy scenario (labeled in the chart as "no tax"), future generations will be worse off than in the business as usual oil policy scenario (labeled in the chart as "tax"). Thus, under the assumption of voracity, the adoption of an oil policy along the optimal extraction path will leave a higher burden for future generations. In other words, no matter the oil policy adopted, when there is fiscal voracity, fiscal policy is unsustainable.

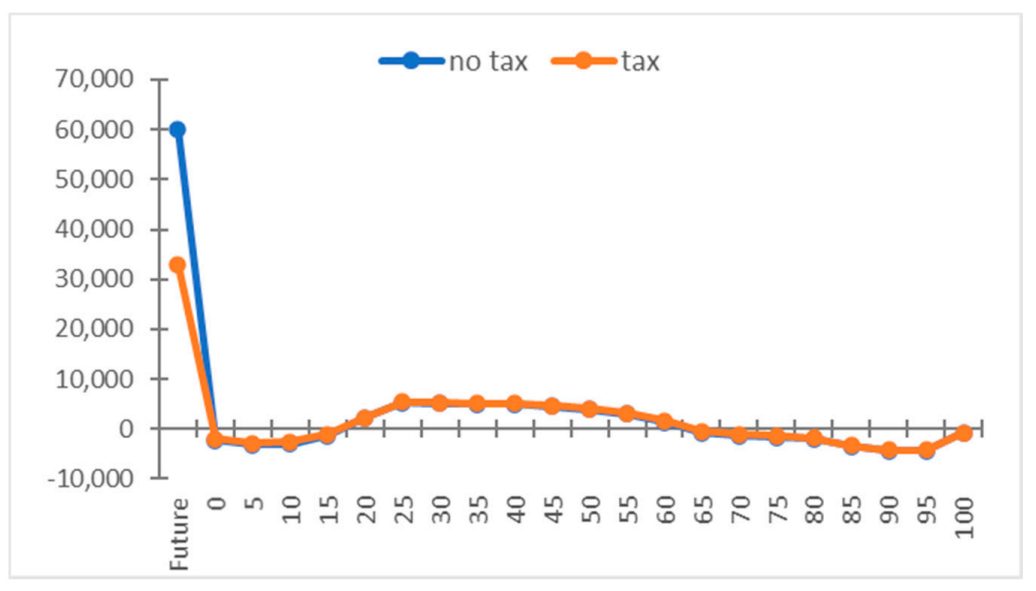

Figure 4. Generational accounts in 2001. Interest rate: $11.35 \%$. Voracity effects included. (In year 2000 U.S. dollars). Source: Authors' calculations.

\section{Intergenerational Distribution of Oil Wealth in Venezuela in 1975 and 1991}

For the argument "because future generations are worse off due to fiscal policy, reforms to oil policy are stalled" to be valid, it should be consistent over time. In this regard, in this section, we compute the intergenerational accounts in two key periods.

It is important to have a brief historical background on the different dates. As argued in Manzano and Monaldi (2010), in 2001, the Venezuelan government started a process of "re-nationalization". While the 2001 attempt failed, since the new Hydrocarbon Law was in a package of 49 laws that was not well received by the opposition and started a long political conflict that even included a coup attempt, once the political situation was solved, the government continued with its expropriation process. Therefore, 2001 is a year that began a process towards a "high tax" oil policy.

Besides 2001, the first period we take is 1991. As argued in Manzano and Monaldi (2010), in 1991 a process of opening up the sector to private investors began. In 1991, the first round of operational agreements was awarded. The process later will include the 
joint-ventures for heavy oil in the Orinoco Belt as well as "exploration-at-risk" agreements for new areas. Consequently, 1991 is a year that begins a process toward a "low tax" policy.

In Figure 5, we present the results for this exercise in the case that we allow for voracity. As in Figures 3 and 4, we read the point in the horizontal axis marked as "0" as the generational account of an individual born in year 1991 and compare it to the point marked as "future", which is the generational account of an average individual born after 1991. As seen in the figure, even though future generations will still receive a "burden" from the current generations, the burden in the scenario with a "low tax" policy is significantly lower than the one in the scenario with higher taxes. Consequently, in 1991, the move towards an oil policy of lower taxes and higher profit sharing was better for future generations.

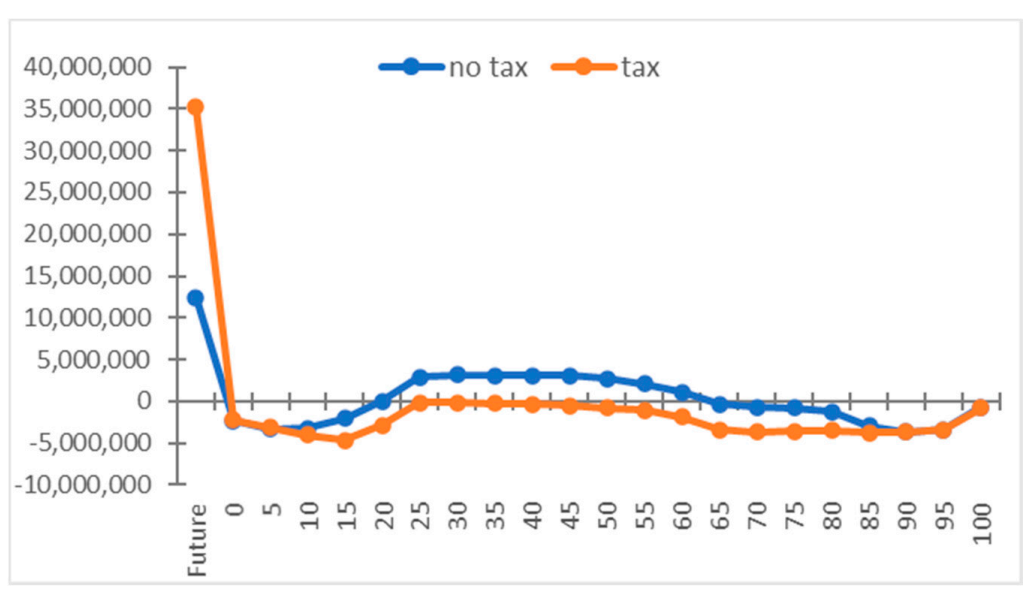

Figure 5. Generational accounts in 1991, interest rate: 11.35\%. Voracity effects included. In year 2000 U.S. dollars. Source: Authors' calculations.

The final period analyzed is 1975 . This period is probably not the best year to take. Ideally, the best year to analyze is 1958, as that period marks the beginning of democracy in Venezuela and with it, the beginning of a push for nationalization. Therefore, the ideal starting point would be 1958. Nevertheless, there are not enough data to complete the generational accounts of that year.

The first year with a complete set of data is 1975 . The nationalization was decreed in 1975. In Manzano (2013) [43], it is argued that actually the fiscal pressure was reduced after the nationalization to allow the new national oil company to invest. Therefore, it is a year hard to "qualify" ex-ante. We will do the exercise for this year as a benchmark.

In Figure 6, we present the exercise for the 1975 generational accounts. As in previous figures, we read the point in the horizontal axis marked as " 0 " as the generational account of an individual born in year 1975 and compare it to the point marked as "future", the generational account of an average individual born after 1975. From the simulation, we see that, again, future generations are better off with an oil policy towards lower taxation. In this case, the situation actually changes from one where future generations are left with a burden in the scenario with taxes, while in the scenario with an optimal oil policy, future generations are left with a fiscal benefit. Consequently, in 1975, the best option for future generations was an oil policy that encouraged production.

However, as we mentioned, 1975 is difficult to judge. On one side, this is the year the industry was nationalized. However, the nationalization was the culmination of the process that started in 1958. Furthermore, after 1975, the tax pressure on the new national oil company was reduced. In Manzano (2013), the period after 1975 was described as "erratic" with regards to the financial management of the asset. Therefore, the year is not easy to judge. 


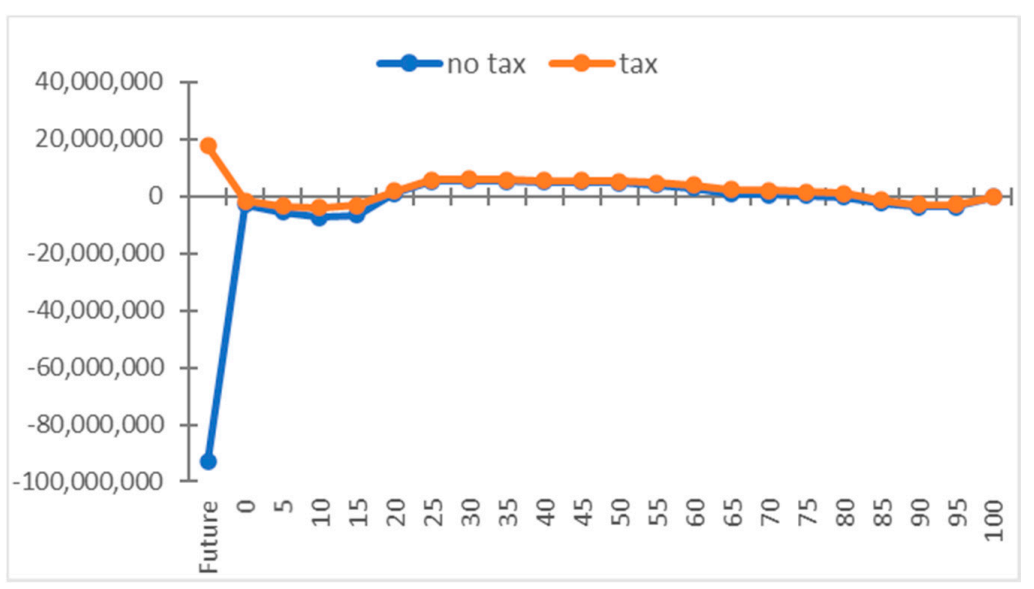

Figure 6. Generational accounts in 1975, interest rate: 11.35\%. Voracity effects included, (in year 2000 U.S. dollars). Source: Authors' calculations.

Nevertheless, what is apparent from an historical perspective is that, if the voracity of the fiscal policy had ended, this indeed implied higher debt in 1975 than in 2001. Figure 7 below shows the ratio of the change in public debt in excess of exports between the beginning and the end of an oil boom. It shows this ratio for the boom of the 1970s and of the 2000s.

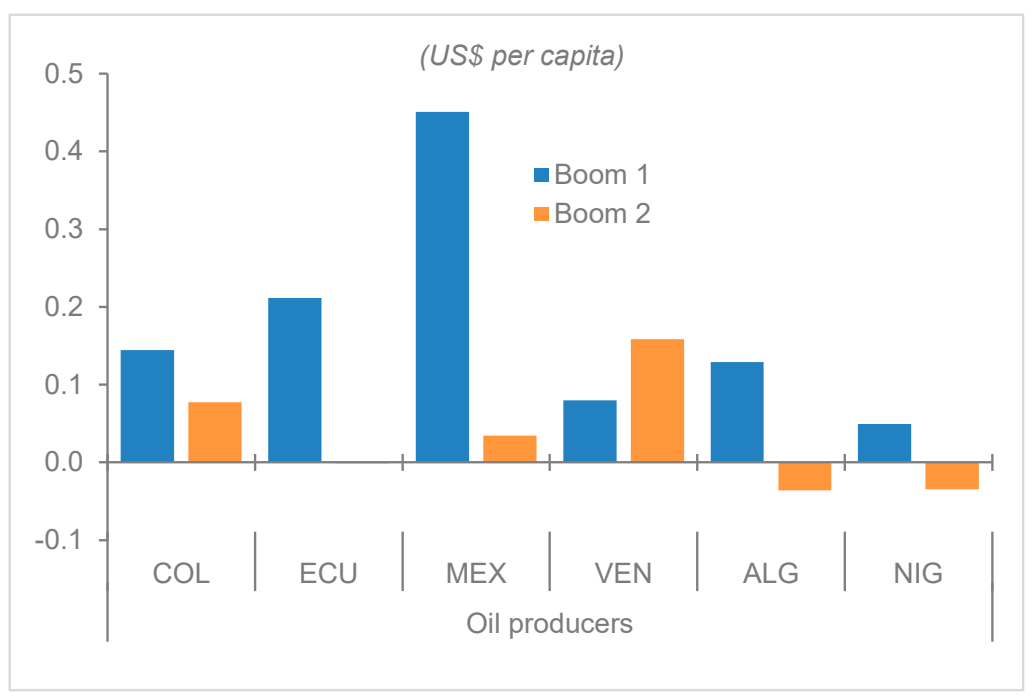

Figure 7. Extra dollar of external debt per extra dollar of exports. Source: IMF, World Bank and Authors' calculations.

As seen in Figure 7, in the boom of the 1970s, Venezuela issued new net debt while oil revenues were increasing. On average, it issued 10 cents of debt per dollar of extra oil revenue. Therefore, instead of saving during the boom, it spent beyond its revenue and indebted itself. However, in that boom, Venezuela was similar to other oil producers.

Nevertheless, in the boom of the 2000s, it behaved in the same way. However, two facts are particular of this boom. Firstly, other oil producers "learnt" from the first boom, and they either did not issue debt or even paid debt. Secondly, Venezuela issued more debt per dollar of export revenue-twice as much-in this boom than in the first one. Therefore, it might have been rational to avoid giving more revenue to the government, because it might have implied higher debt. When prices collapsed, Venezuela eventually defaulted on its debt and entered a profound recession. 


\section{Conclusions}

Over the last 40 years, Venezuelan oil production has not seemed to follow an optimal production path. Exploiting oil at a historical rate is a sub-optimal strategy since future generations are less benefited by this path. The outcome of an intergenerational accounting model suggests that it would be more convenient, for future generations, to have oil exploited following an optimal path in order to decrease their generational burdens. Nevertheless, this is true if we do not consider what the government does with the resources received from the oil sector.

Moreover, by exploring the interaction of oil policy and fiscal policy, we found that these interactions could explain certain outcomes:

In 1991, the Venezuelan government started a process to open the sector to private investors and increase production. Using an intergenerational accounting model, we found that this policy improved the fiscal account of future generations, even considering the fiscal response of the government.

In contrast, in 2001, the Venezuelan government started a process of expropriation that effectively increased the tax rate in the sector, reducing its growth perspectives. Using the same intergenerational accounting model, we found that an optimal production path would have worsened the fiscal accounts of future generations, given the fiscal response of the government.

In 1975, the intergenerational accounting model found that an optimal production policy would have improved the fiscal accounts of future generations, even considering the fiscal response of the government. 1975 is a particular year, even though it is when the oil sector was nationalized; this nationalization was the culmination of a process, rather than an unexpected move, and fiscal pressure on the sector was actually reduced after that. Therefore, is not clear how to "classify" the year.

These results seem to suggest that there is an interdependence between oil policy and fiscal policy. Voters seems to allow a more production-oriented oil policy if fiscal policy is prudent. Nevertheless, when fiscal policy could leave an important burden to future generations, voters seem to favor a more tax-oriented oil policy.

The next question is why there have been no changes to the elements that lead to the manner in which fiscal policy is managed. This escapes the goal of this paper. Nevertheless, it is important to mention recent literature on this front that has found that there are important institutional issues in Venezuela that prevent a better fiscal policy. For a comprehensive study of these institutional issues in Venezuela, see González et al. (2004) [44] and González et al. (2004) [45].

These institutional issues are sometimes embedded in the constitution. Therefore, the change of the elements that lead towards an unsustainable fiscal policy might require a higher level of coordination that could be difficult to achieve.

Finally, it is important to mention that going forward, the context has changed significantly. After the Paris Agreement, decarbonization, or the transition towards a low-carbon economy, low-fossil-fuel economy, has accelerated. This could imply a lower demand for Venezuelan oil and lower fiscal revenues. For a study of these implications, see SolanoRodríguez et al. (2019) [46]. Therefore, a new consideration for oil policy is the time horizon of the demand for Venezuelan oil.

Author Contributions: Conceptualization, O.M. and J.L.S.; methodology, O.M..; software, J.L.S.; validation, O.M. and J.L.S.; formal analysis, O.M. and J.L.S.; investigation, O.M. and J.L.S.; resources, O.M. and J.L.S.; data curation, O.M. and J.L.S.; writing-original draft preparation, O.M. and J.L.S.; writing - review and editing, O.M. and J.L.S.; visualization, O.M. and J.L.S. All authors have read and agreed to the published version of the manuscript.

Funding: This research received no funding.

Data Availability Statement: Publicly available datasets were analyzed in this study.

Conflicts of Interest: The authors declare no conflict of interest. 


\section{Appendix A. Oil Scenarios}

The basic model follows Medina (1997) and Deacon (1993). The framework is the traditional Hotelling model:

The producer maximizes profits according to the following function, which represents the net present value of profits:

$$
\max _{q, T, w} \int\left[p y_{t}-c\left(y_{t}\right)-c\left(w_{t}\right)\right] e^{-r t} d t
$$

where:

$y_{t}=$ represents the extraction at time $t$

$c\left(y_{t}\right)=$ the extraction cost function which have the following functional form:

$$
c\left(y_{t}\right)=\theta y_{t}^{\varepsilon} R_{t}^{1-\varepsilon}
$$

$R_{t}$ representing oil reserves.

$c\left(w_{t}\right)$ represents the cost of investing in $w_{t}$ wells. It has the following functional form:

$$
c\left(w_{t}\right)=a+b w_{t}+c w_{t}^{2}
$$

Reserves accumulate according to the following functional forms:

$$
\begin{gathered}
R_{t}=d_{t}-y_{t} \\
d_{t}=D_{t}-D_{t-1} \\
D_{t}=\Gamma\left(1-e^{-\beta w_{t}}\right) \\
w_{t}=W_{t}-W_{t-1}
\end{gathered}
$$

We use the parameters of Medina (1997). For the "business as usual" scenario, we include government taxation in the forms of royalties and income tax.

Using this model and the assumptions given, Figure A1 presents the different scenarios.

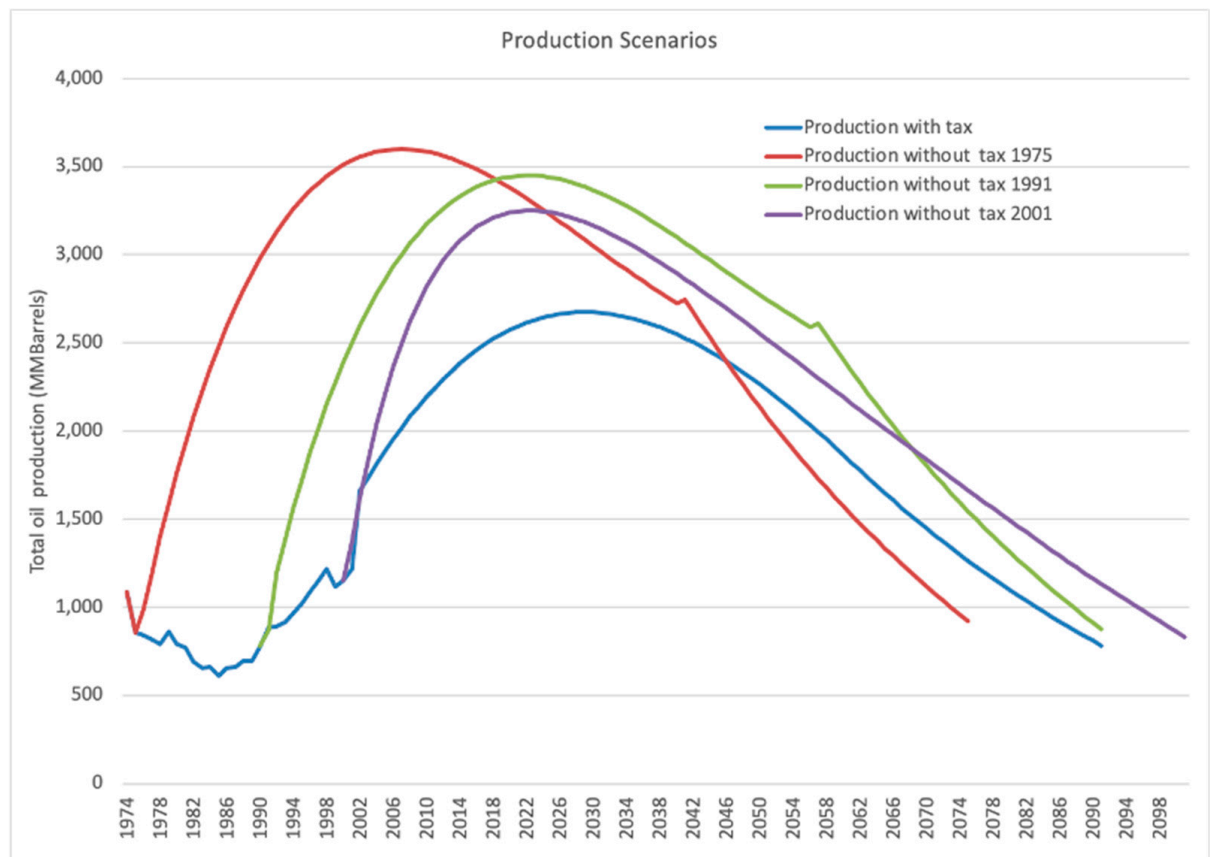

Figure A1. Oil production scenarios. Source: Authors' calculations. 


\section{Appendix B. Intergenerational Imbalance Scenarios}

We propose 48 different scenarios, in which we use different data and assumptions for the simulations:

(1) Oil exploitation scheme: historic (business as usual) or optimal.

(2) Government operating expenditures: Constant per capita expenditures (generational justice) or fiscal voracity.

(3) Interest rates: potential (5\%) or historical (11.35\%).

(4) Growth rates: average total GDP growth rate for the 1958-2000 period (3.56\%) or optimistic "non-oil dependent" GDP growth rate $(0 \%)$.

Results are presented in the following panels, one for each analyzed year:
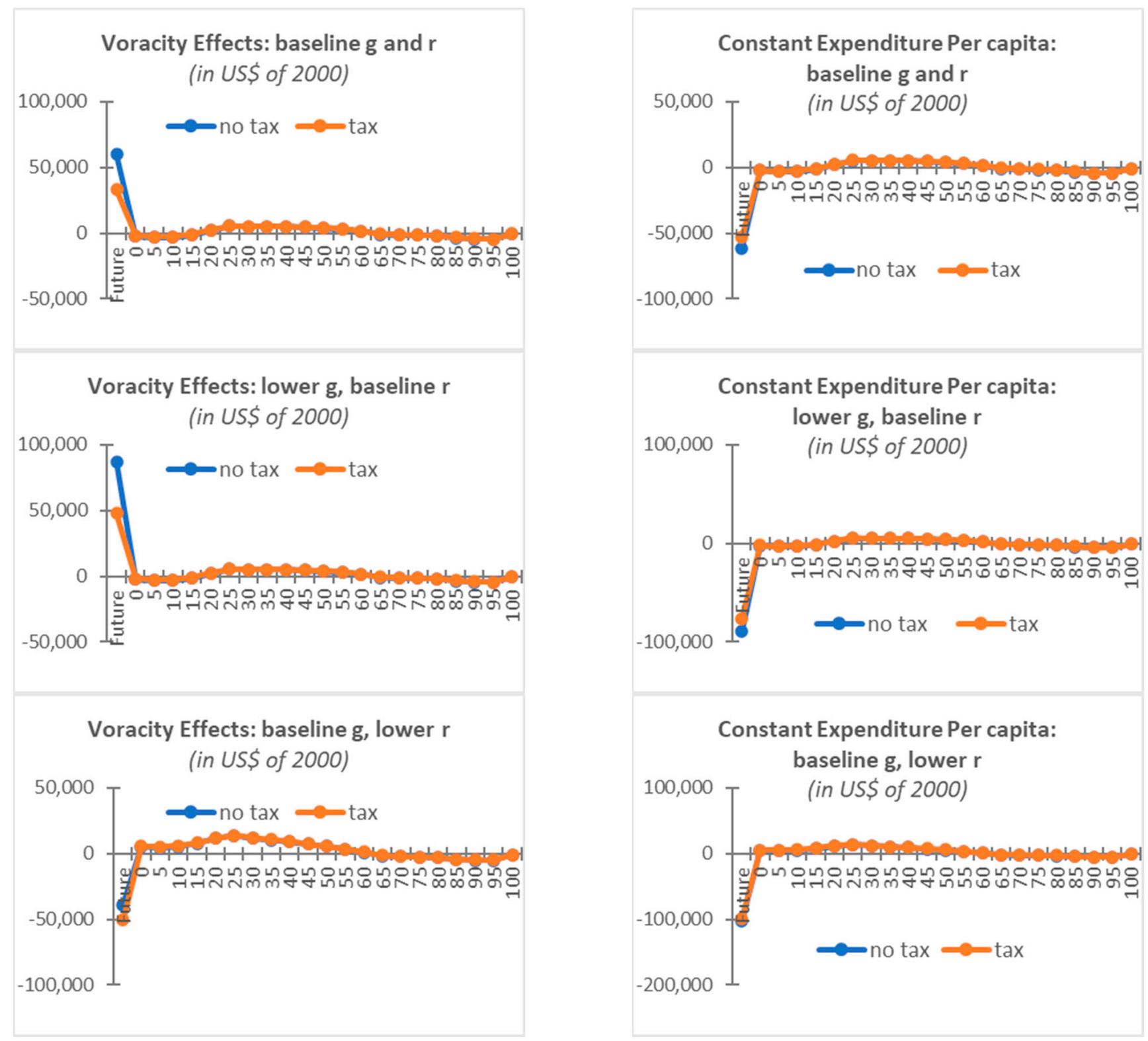

Figure A2. Cont. 

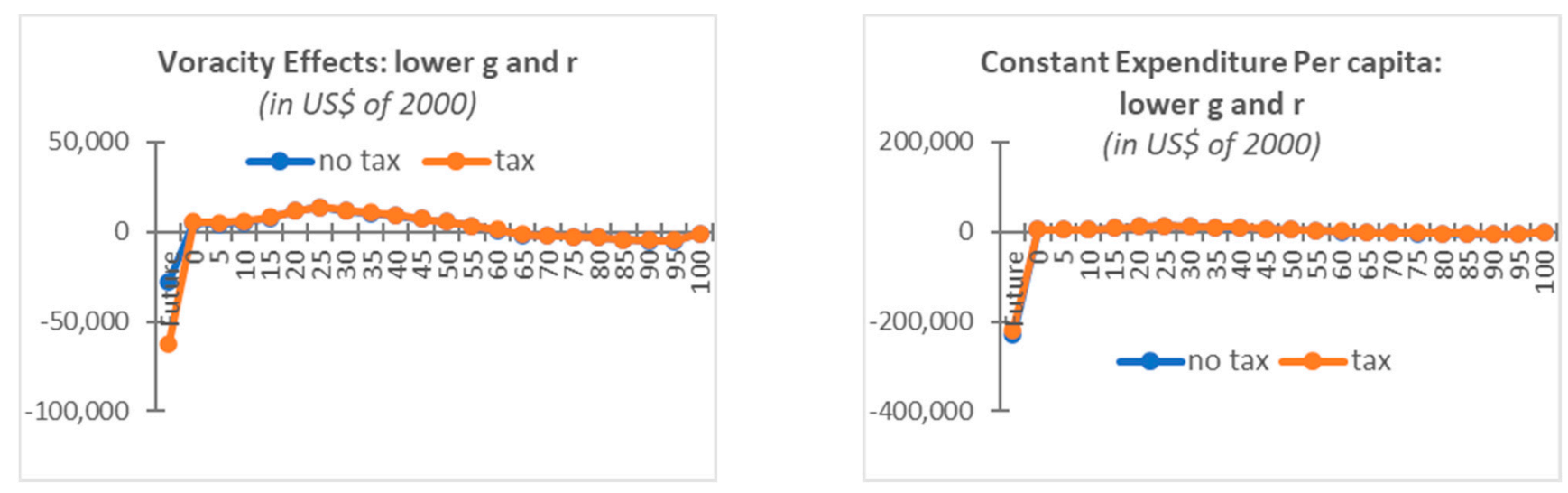

Figure A2. Generational accounts in 2001.
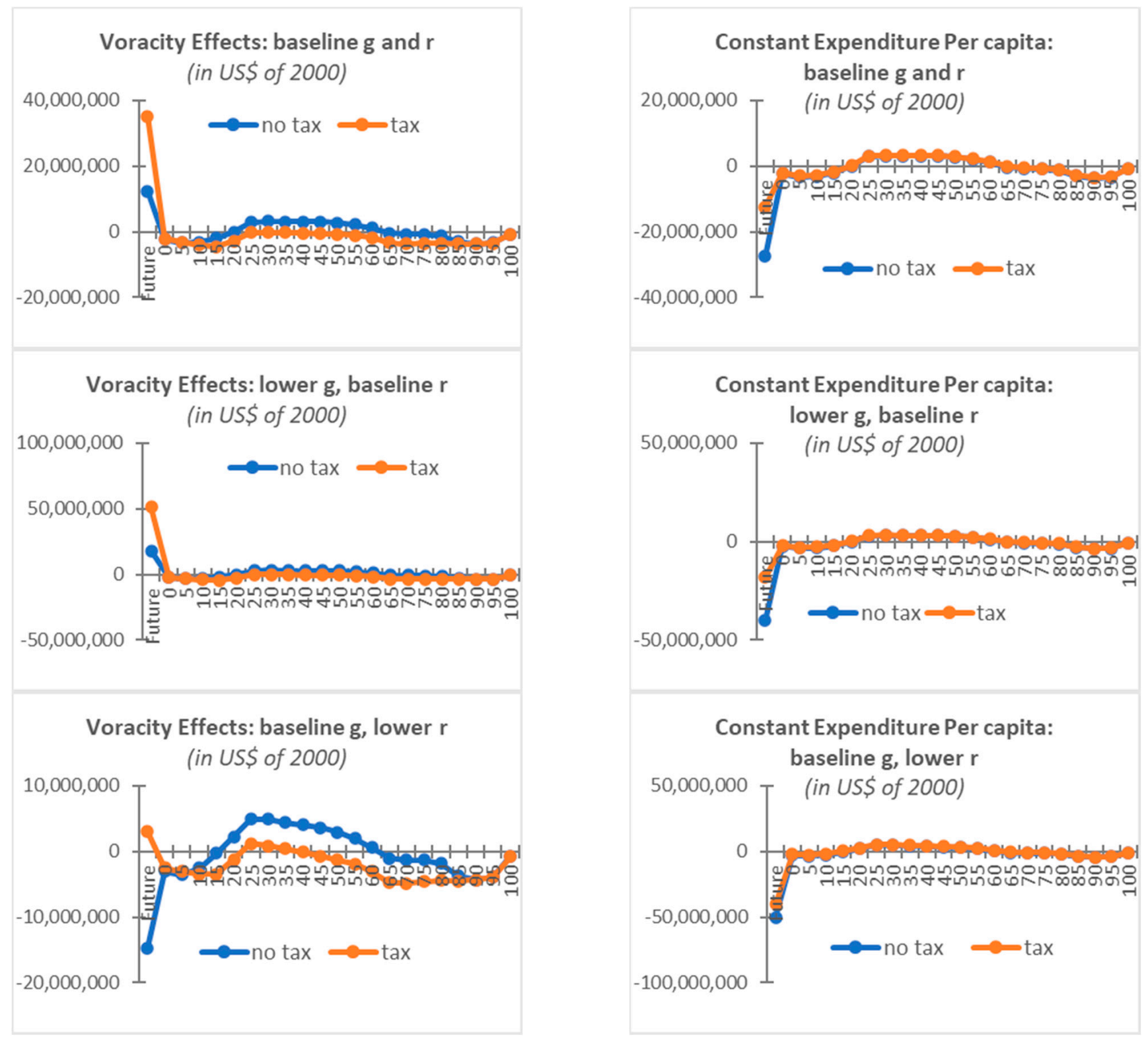

Figure A3. Cont. 
Voracity Effects: lower $\mathrm{g}$ and $\mathrm{r}$ (in US\$ of 2000)

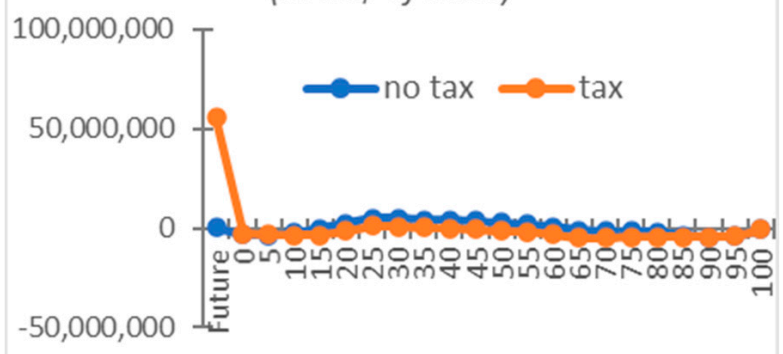

\section{Constant Expenditure Per capita:} lower $g$ and $r$

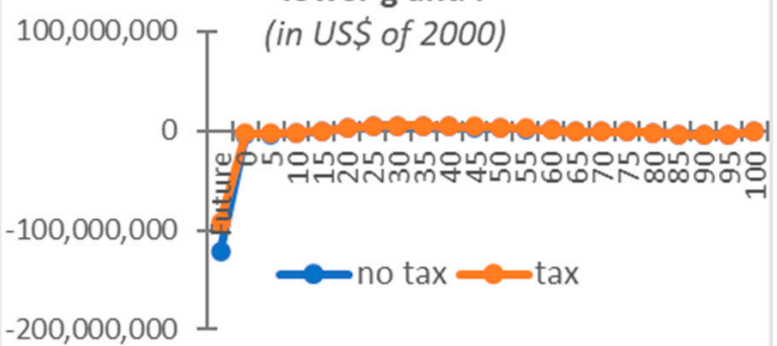

Figure A3. Generational accounts in 1991.
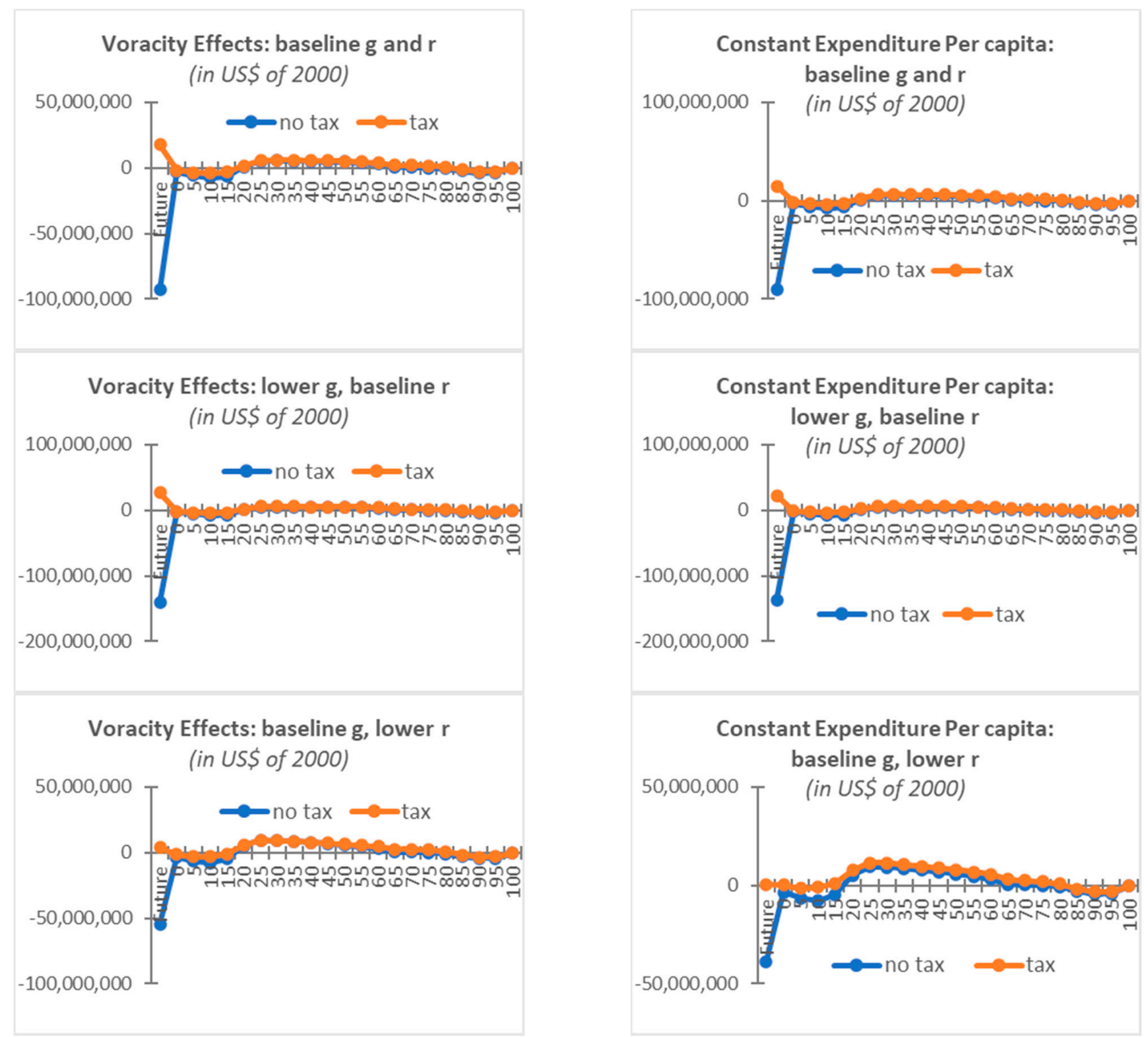

Figure A4. Cont. 

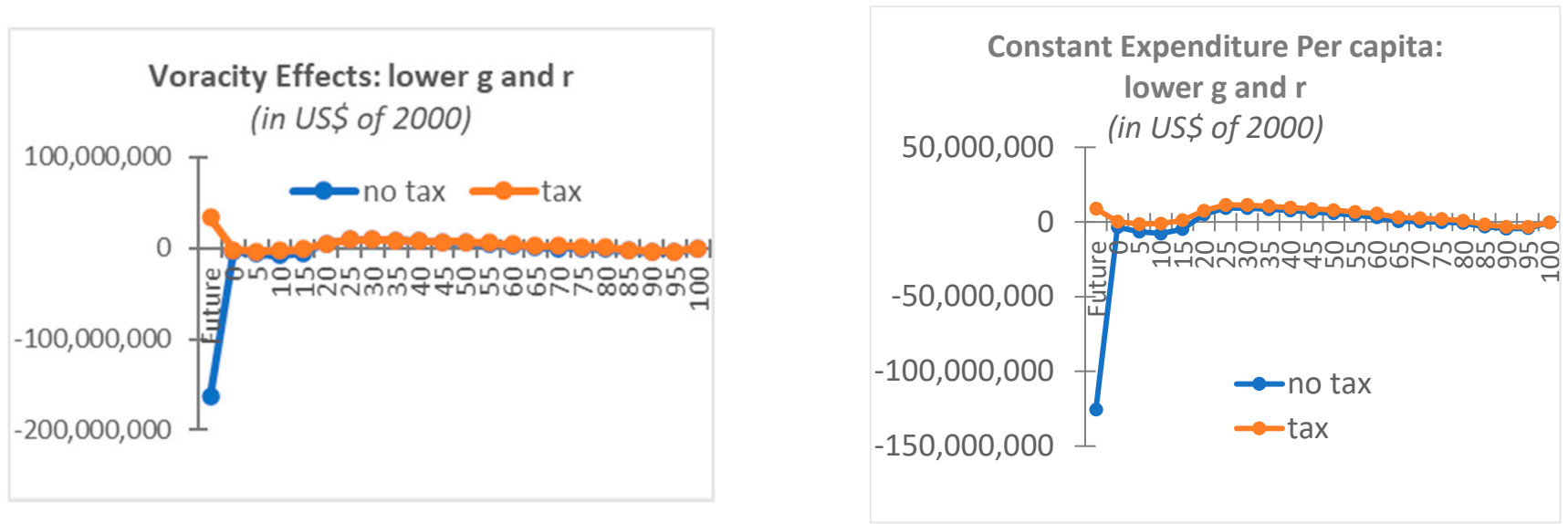

Figure A4. Generational accounts in 1975.

\section{Appendix C. Government Expenditures Elasticity to Oil Revenues}

Table A1 below shows the results of the government expenditures elasticity to oil income regressions. The following regressions were estimated

The first block of regressions, columns 1 to 3 in Table A1, was performed with the variables in logarithmic differences. Using yearly data, the first column estimates the elasticity of government spending to oil income (controlling for variables' first lags and private consumption) over the whole sample (1959-2000). The second column covers only the episodes of positive changes on oil income, and the third column covers only the episodes of negative changes on oil income. The estimated equation is the following:

$$
\Delta \exp _{t}=\alpha+\beta \Delta \text { oilinc }_{t}+\gamma \Delta \text { privcon }_{t}+\text { Slags }_{t-1}+\text { trend }_{t}+\varepsilon_{t}
$$

where:

exp is the logarithmic change of government expenditures in U.S. dollars of the year 2000. oilinc is the logarithmic change of government spending in U.S. dollars of the year 2000. privcon is the logarithmic change of government spending in U.S. dollars of the year 2000. lags is a vector of these variables' first lags

trend is a time trend

$\alpha$ is a constant term

$\beta$ is government expending elasticity to oil income

$\gamma$ is government spending elasticity to private consumption

$\delta$ and $\theta$ are the lags and time trend coefficients, respectively, and

$\varepsilon$ is the estimation's error term.

The second block of regressions, columns 4 to 6 , repeat the same exercise, but instead of using log differences, the variables are as a share of the corresponding years' GDP in U.S. dollars of the year 2000. The estimated equation was the following:

$$
\exp \__{-} d p_{t}=\alpha+\beta \text { oilinc_gd } p_{t}+\gamma \text { privcon_gd } p_{t}+\text { Slags }_{t-1}+\theta \text { trend }_{t}+\varepsilon_{t}
$$

where all the variables are the same as above but, instead of being expressed in log differences, are expressed as a share of GDP. 
Table A1. Government expenditure elasticity to oil income.

\begin{tabular}{|c|c|c|c|c|c|c|}
\hline \multirow{3}{*}{$\begin{array}{c}\text { Dependent Variable: } \\
\text { Government Expenditures }\end{array}$} & \multicolumn{3}{|c|}{ Log Differences } & \multicolumn{3}{|c|}{ Shares of Trend GDP } \\
\hline & All & $>0$ & $<0$ & All & $>0$ & $<0$ \\
\hline & (1) & (2) & (3) & (4) & (5) & (6) \\
\hline Constant & -0.015 & -0.134 & 0.032 & -1.690 & $-6.866^{* *}$ & 1.550 \\
\hline std. error & 0.059 & 0.084 & 0.079 & 1.980 & 2.356 & 2.631 \\
\hline Oil income & $0.666^{* * *}$ & $1.510^{* * *}$ & 0.285 & $1.354 * * *$ & $2.198^{* * *}$ & 0.620 \\
\hline std. error & 0.144 & 0.337 & 0.315 & 0.217 & 0.314 & 0.461 \\
\hline Private consumption & $0.844^{* *}$ & $2.284^{* * *}$ & 0.236 & $0.614^{* *}$ & $1.473^{* * *}$ & 0.176 \\
\hline std. error & 0.388 & 0.719 & 0.412 & 0.260 & 0.478 & 0.259 \\
\hline Government expenditures, 1st lag & $-0.383^{* *}$ & $-0.926^{*}$ & $-0.276^{*}$ & -0.275 & $-0.908^{* *}$ & -0.164 \\
\hline std. error & 0.164 & 0.449 & 0.148 & 0.169 & 0.399 & 0.160 \\
\hline Oil income, 1st lag & 0.259 & 0.137 & 0.155 & 0.341 & 0.290 & 0.026 \\
\hline std. error & 0.172 & 0.394 & 0.165 & 0.301 & 0.496 & 0.288 \\
\hline Private consumption, 1st lag & 0.413 & 0.578 & 0.322 & 0.238 & 0.341 & -0.075 \\
\hline std. error & 0.320 & 0.417 & 0.474 & 0.228 & 0.275 & 0.302 \\
\hline Time trend & -0.001 & -0.005 & -0.003 & 0.021 & 0.002 & -0.059 \\
\hline std. error & 0.002 & 0.003 & 0.003 & 0.069 & 0.084 & 0.084 \\
\hline Observations & 42 & 20 & 22 & 42 & 20 & 22 \\
\hline R-squared & 0.456 & 0.671 & 0.282 & 0.584 & 0.843 & 0.347 \\
\hline Adjusted R-squared & 0.363 & 0.519 & -0.005 & 0.513 & 0.770 & 0.086 \\
\hline S.E. of regression & 0.156 & 0.159 & 0.125 & 5.194 & 4.492 & 4.060 \\
\hline Sum squared residuals & 0.850 & 0.329 & 0.235 & 944.377 & 262.263 & 247.239 \\
\hline Log likelihood & 22.303 & 12.687 & 18.699 & -124.965 & -54.115 & -57.829 \\
\hline F-statistic & 4.892 & 4.419 & 0.982 & 8.197 & 11.619 & 1.330 \\
\hline Prob(F-statistic) & 0.001 & 0.012 & 0.471 & 0.000 & 0.000 & 0.304 \\
\hline Durbin-Watson stat & 1.985 & 2.007 & 3.462 & 1.958 & 3.123 & 2.786 \\
\hline
\end{tabular}

Source: Authors' calculations. ${ }^{* * *} p$-value $<0.01,{ }^{* *} p$-value $<0.05,{ }^{*} p$-value $<0.1$.

\section{References}

1. Prebisch, R. The Economic Development of Latin America and Its Principal Problems, United Nations Department of Economic Affairs; Economic Commission for Latin America (ECLA): New York, NY, USA, 1950.

2. Salter, W.E. Internal and External Balance: The Role of Price and Expenditure Effects. Econ. Rec. 1959, 35, 226-238. [CrossRef]

3. Sachs, J.D.; Warner, A.M. Natural Resource Abundance and Economic Growth; NBER Working Papers 5398; National Bureau of Economic Research, Inc: Cambridge, MA, USA, 1995.

4. Sachs, J.D.; Warner, A.M. Natural Resource Abundance and Economic Growth; Working Paper; Center for International Development and Harvard Institute for International Development: Cambridge, MA, USA, 1997.

5. The Dutch Disease. The Economist, 26 November 1977; 82-83.

6. Georgescu-Roegen, N. Energy and Economic Myths: Institutional and Analytical Economic Essays; Pergamon Press: New York, NY, USA, 1976.

7. Lederman, D.; Maloney, W.F. Natural Resources: Neither Curse nor Destiny; World Bank: Washington, DC, USA; Stanford University Press: Palo Alto, CA, USA, 2007.

8. Jean-Philippe, S. An Empirical Test of the Dutch Disease Hypothesis Using a Gravity Model of Trade; mimeo, UC Berkley. 2003. Available online: https:/ / papers.ssrn.com/sol3/Delivery.cfm/SSRN_ID403041_code030513600.pdf?abstractid=403041\&mirid=1 (accessed on 30 March 2021).

9. Aizeman, J.; Pinto, B. Managing Economic Volatility and Crises: A Practitioner's Guide; The World Bank: Washington, DC, USA, 2005.

10. Hausmann, R.; Rigobon, R. An Alternative Interpretation of the 'Resource Curse': Theory and Policy Implications; NBER Working Papers 9424; National Bureau of Economic Research, Inc: Cambridge, MA, USA, 2003.

11. Manzano, O. Vulnerabilidad Externa y Volatilidad Económica [External vulnerability and macroeconomic volatility]. In Corporación Andina de Fomento; Temas Críticos para América Latina en el Siglo XXI; Publicaciones CAF: Quito, Ecuador, 2002.

12. Manzano, O.; Rigobon, R. Resource Curse or Debt Overhang. In Natural Resources: Curse or Destiny; Lederman, D., Maloney, W., Eds.; Stanford University Press: Washington, DC, USA, 2007.

13. Engel, E.; Valdes, R. Optimal Fiscal Strategy for Oil Exporting Countries. IMF Working Paper WP/00/118. 2000. Available online: https:/ / www.imf.org/external/pubs/ft/wp/2000/wp00118.pdf (accessed on 30 March 2021).

14. Sachs, J.D. How to Handle the Macroeconomics of Oil Wealth; Initiative for Policy Dialogue Working Paper Series. 2006. Available online: https:/ / policydialogue.org/files/publications/papers/Ch07.pdf (accessed on 30 March 2021).

15. van der Ploeg, F.; Venables, A. Natural Resource Wealth: The Challenge of Managing a Windfall. Annu. Rev. Econ. 2008, 4, 315-337. [CrossRef] 
16. Alberola, E.; Benigno, G. Revisiting the commodity curse: A financial perspective. J. Int. Econ. 2017, 107, 87-106. [CrossRef]

17. Raddatz, C. Are External Shocks Responsible for the Instability of Output in Low-Income Countries? Bank Policy Research Working Paper No. 3680; The World Bank: Washington, DC, USA, 2005.

18. Hogan, W.; Sturzzeneger, F. The Natural Resources Trap: Private Investment without Public Commitment; MIT Press: Cambridge, UK, 2010.

19. Manzano, O.; Monaldi, F. The Political Economy of Oil Production in Latin America, Economia; Brookings/LACEA Publications: Washington, DC, USA, 2008; Volume 9, No. 1.

20. Manzano, O.; Monaldi, F. The Political Economy of Oil Contract Renegotiation in Venezuela. In The Natural Resources Trap: Private Investment without Public Commitment; Hogan, W., Sturzzeneger, F., Eds.; MIT Press: Cambridge, UK, 2010.

21. Auerbach, A.; Gokhale, J.; Kotlikoff, L. Generational accounts: A meaningful alternative to deficit accounting. In Tax Policy and the Economy; Bradford, D., Ed.; The MIT Press: Cambridge, MA, USA, 1991.

22. Videgaray, L. The Fiscal Response To Oil Shocks, Dissertation Submitted to the Department of Economics in Partial Fulfillment of the Requirements for the Degree of Doctor in Philosophy at the Massachusetts Institute of Technology; MIT: Cambridge, UK, 1998.

23. Bozzari, E.; Rincon, J. Effects of oil shocks on Fiscal Expenditures and Non-Oil Taxes. A Study for Venezuela 1960-2000. Research Thesis presented to obtain the bachelor's degree in Economics. Bachelor's Thesis, Universidad Católica Andrés Bello, Caracas, Venezuela, 2005.

24. van den Bremer, T.; van der Ploeg, F.; Wills, S. The Elephant in the Ground: Managing Oil and Sovereign Wealth. Eur. Econ. Review 2016, 82, 113-131. [CrossRef]

25. Fernández, A.J.; Gómez, J. Application of Different Schemes of Savings Funds and Their Intergenerational Effects in Venezuela; Publicaciones del Banco Central de Venezuela: Caracas, Venezuela, 2002.

26. Auerbach, A.; Kotlikoff, L.; Leibfritz, W. Generational Accounting around the World; Chicago University Press: Chicago, IL, USA, 1999.

27. Laub, N.; Hagist, C. Pension and Intergenerational Balance-A case study of Norway, Poland and Germany using Generational Accounting. Intergener. Justice Rev. 2017, 2, 64-77.

28. Arévalo, P.; Berti, K.; Caretta, A.; Eckefeldt, P. The Intergenerational Dimension of Fiscal Sustainability, No 112, European Economy; Discussion Papers 2015; Directorate General Economic and Financial Affairs (DG ECFIN), European Commission: Brussels, Belgium, 2019.

29. Medina, H. Evaluación de los Efectos de Diferentes Esquemas Impositivos Sobre la Senda Exploración y Producción de una Empresa Petrolera en el Tiempo (un Análisis Para el Caso Venezolano); Mimeo, PDVSA: Caracas, Venezuela, 1997.

30. Deacon, R.T. Taxation, Depletion, and Welfare: A Simulation Study of the U.S. Petroleum Resource. JEEM J. Environ. Econ. Manag. 1993, 24, 159-187. [CrossRef]

31. Pérez Alfonzo, J. Política Petrolera; Imprenta Nacional: Caracas, Venezuela, 1962.

32. Urbaneja, D. Pueblo y Petróleo en la Política Venezolana del Siglo XX; Ediciones CEPET: Caracas, Venezuela, 1992.

33. Baptista, A.; Mommer, B. El Petróleo en el Pensamiento Económico Venezolano, 2da Edición (Revisada); Ediciones IESA: Caracas, Venezuela, 1992.

34. Ministerio de Energía y Minas (MEM). Petróleo y Otros Datos Estadísticos; Dirección de Economía e Hidrocarburos: Caracas, Venezuela, various years.

35. International Financial Statistics-International Monetary Fund (IMF). Available online: https:/ / data.imf.org/?sk=4c514d48-b6 ba-49ed-8ab9-52b0c1a0179b (accessed on 30 March 2021).

36. Georgescu-Roegen, N. Energy Analysis and Economic Valuation. South. Econ. J. 1979, XLIV, 1023-1058. [CrossRef]

37. Manzano, O. Managing Hydrocarbon Assets: A Comparison across the Atlantic. In The Future of Energy in the Atlantic Basin, Center for Transatlantic Relations; Eloy, Á., Isbell, P., Eds.; The Johns Hopkins University: Washington, DC, USA, 2015.

38. Cuddington, J.; Ludema, R.; Jayasuriya, Y.S. Prebisch-Singer Redux. In Natural Resources: Curse or Destiny; Lederman, D., Maloney, W., Eds.; Stanford University Press: Stanford, CA, USA, 2007.

39. Rigobón, R. Características del Proceso Estocástico del Petróleo; Mimeo MIT: Caracas, Venezuela, 1999.

40. Smith, J. Analysis of the Petroleum Fiscal Framework of Venezuela; IADB Technical Note IDB-TN-1985; Inter-American Development Bank: Washington, DC, USA, 2020.

41. Davis, G.; Smith, J. Design and Performance of Mining and Petroleum Fiscal Regimes in Latin America and the Caribbean: Survey of Current Practices, Lessons Learned and Best Practices, IDB Monograph 831; Inter-American Development Bank: Washington, DC, USA, 2020.

42. Lane, P.; Tormell, A. Are Windfalls a Curse? A Non-Representative Agent Model of the Current Account; NBER Working Paper n. 4839; NBER: Cambridge, UK, 1998.

43. Manzano, O. Venezuela after a Century of Oil Exploitation. In Venezuela before Chávez: Anatomy of an Economic Collapse; Hausmann, R., Francisco, R., Eds.; Penn-State University Press: University Park, PA, USA, 2013.

44. González, M.; Monaldi, F.; Rios, G.; Villasmil, R. Understanding Reform Country Study: Venezuela, Mimeo; Global Development Network: Washington, DC, USA, 2004.

45. González, R.A.; Monaldi, F.; Obuchi, R.; Penfold, M. Political Institutions, Policy Making Processes and Policy Outcomes in Venezuela, Mimeo; Latin American Research Network, IADB: Washington, DC, USA, 2004.

46. Solano-Rodríguez, B.; Pye, S.; Li, P.H.; Ekins, P.; Manzano, O.; Vogt-Schilb, A. Implications of Climate Targets and Fiscal Policy on Oil Production and Revenues in Latin America and the Caribbean; IADB Discussion Paper IDB-DP-00701; Inter-American Development Bank: Washington, DC, USA, 2019. 